\title{
A future for hydrogen in European transportation
}

\author{
Europe is following in the steps of Japan and California towards the implementation of fuel cell vehicles. We revisit \\ the current state of affairs in Europe while one of its flagship projects is nearing its end.
}

T he 2015 Paris climate conference culminated with a universal, legally binding global climate agreement signed by 195 states, setting out a plan to limit the average temperature increase to below $2{ }^{\circ} \mathrm{C}$ above pre-industrial levels ${ }^{1}$. To achieve the goal a significant decrease in greenhouse gas emissions must be undertaken globally - estimated at $25 \%$ by 2030, with the threshold reaching 50\% if the more ambitious $1.5^{\circ} \mathrm{C}$ target is to be achieved $^{2}$.

In Europe, road transportation is responsible for almost $20 \%$ of total greenhouse gas emissions ${ }^{3}$. The European Commission introduced the Clean Mobility Package in 2017, a plan to accelerate the transition to low- and zero-emission vehicles, together with a targeted $60 \%$ reduction of greenhouse gas emissions by 2050 with respect to 1990 levels. In addition to battery-powered electric vehicles, fuel cell electric vehicles (FCEVs) represent a central part of the strategy. In fact, in 2008 the European Commission partnered with the fuel cell and hydrogen industries as well as the research community to create the Fuel Cells and Hydrogen Joint Undertaking (FCH JU) programme, which currently involves more than 130 companies, over 70 research organizations and 19 national and regional associations. This consortium has so far funded over 250 projects. Under the FCH JU programme, the Hydrogen Mobility Europe projects, building from an alliance of four regional initiatives in Germany, France, Scandinavia and the United Kingdom, work on the deployment of FCEVs in Europe, including a transnational network of hydrogen refuelling stations. The first of the Hydrogen Mobility Europe projects started in 2015 and will end in May 2020.

However, the sales of FCEVs in Europe fall far below those in the Asia-Pacific and North America regions. This contrasts with the amount of refuelling stations per region. Due in part to the efforts of the initiatives outlined above, there are currently $130 \mathrm{H}_{2}$ stations in Europe ${ }^{4}, 82$ of them in Germany, and about 50 more under development -
Berlin, where Nature Catalysis is based, has five stations, with two more under way. Japan has roughly the same number ${ }^{5}$ (107 in May 2019, and an expected 160 by 2020) whereas the United States has around 50 refuelling stations, 43 of them in California ${ }^{6}$.

\section{"Catalysis research is and will continue to be crucial to achieve more competitive prices, as a big part of the stack cost comes from the catalyst on both the anode and the cathode."}

Where Europe does seem to be taking the initiative is in implementing fuel cell electric bus fleets ${ }^{7}$. A series of projects within FCH JU have put Europe in the spotlight. The Joint Initiative for Hydrogen Vehicles across Europe is deploying nearly 300 fuel cell buses in 22 European cities by 2020 , which will be complemented with 600 buses from the H2Bus consortium in the United Kingdom, Denmark and Latvia by 2023. In contrast, related initiatives in California, Japan and South Korea have so far been less ambitious ${ }^{8-10}$.

From the customer's perspective the main issues that prevent widespread adoption of private FCEVs, especially compared to other electric vehicles that have successfully broken into the market, are their price and the availability of hydrogen refuelling stations. As stated above, the latter is being taken care of at least in specific regions such as Europe, Japan, South Korea, eastern China and California, with multiple projects under way. Regarding the former (an investment of around $€ 70,000$, depending on the model), catalysis research is and will continue to be crucial to achieve more competitive prices, as a big part of the stack cost comes from the catalyst on both the anode and the cathode ${ }^{11}$. There is a need to decrease the platinum group metals' loading or to develop precious-metal-free catalysts with comparable activity and durability $^{12}$. Another research front that can make FCEVs more affordable concerns the production of $\mathrm{H}_{2}$, where catalysis also plays a major role. Current prices are around $€ 0.10$ per $\mathrm{km}$ (ref. ${ }^{13}$ ), which is just slightly more expensive than a conventional combustion engine car. On-site $\mathrm{H}_{2}$ stations produce hydrogen from water electrolysis and hence further research on anodic and cathodic catalysts for acidic and alkaline electrolysers will enable cheaper refuelling.

It has become clear that societies must adapt to minimize their environmental impact and, together with other industries, the transportation sector has to tag along. In decreasing greenhouse gas emissions, the market share of electric vehicles - including FCEVs - will necessarily have to increase in the coming years. For the particular case of Europe, while it currently lags behind Japan and the United States in terms of sales, its infrastructure and public transportation deployment suggest a bright future.

Published online: 19 February 2020 https://doi.org/10.1038/s41929-020-0438-9

References

1. Adoption of the Paris Agreement FCCC/CP/2015/L.9/Rev.1 (UNFCCC, 2015).

2. Emissions Gap Report (UN Environment Programme, 2019); https://www.unenvironment.org/resources/emissions-gapreport-2019

3. Greenhouse Gas Emissions from Transport in Europe (European Environment Agency, accessed 3 February 2020); https:// go.nature.com/371UIKZ

4. https://h2.live/

5. Klippenstein, M. Exclusive: hydrogen station lessons from Japan's JHyM. FuelCellsWorks (5 November 2019); https://go.nature. com/2vQ0keg

6. Alternative Fuels Data Center (Energy Efficiency \& Renewable Energy, accessed 3 February 2020); https://afdc.energy.gov/states/ca

7. https://www.fuelcellbuses.eu/

8. Fuel Cell Transit Bus Evaluations (National Renewable Energy Laboratory, 2018); https://go.nature.com/2GW3QpV

9. Moore, A. Toyota fuel cell buses expected to be big seller of hydrogen at 2020 Tokyo Olympics. Hydrogen Fuel News (20 September 2019); https://go.nature.com/2GZP4OV

10. Hyundai puts hydrogen powered buses into service in Seoul. FuelCellsWorks (23 November 2018); https://go.nature. com/2UuaFac

11. Thompson, S. T. \& Papageorgopoulos, D. Nat. Catal. 2, 558-561 (2019).

12. Pivovar, B. Nat. Catal. 2, 562-565 (2019).

13. https://www.shell.de/energie-und-innovation/mobilitaet/ wasserstoff.html 